\title{
TREATING NEONATAL SEIZURES: IS GABA STILL EXCITING AFTER BIRTH?
}

\author{
S.M. Miller, V.P. Kalanjati, Z. Ireland, P.B. Colditz, S.T. Bjorkman
}

Perinatal Research Centre, UQ Centre for Clinical Research, The University of Queensland, Brisbane,
QLD, Australia

Background and aims: Antiepileptic drugs (AEDs) do not effectively control seizures in newborn brain and there is growing concern that use of standard AEDs such as phenobarbital may exacerbate seizures and brain injury. Recent data suggests this may be due to the changing role of the $\mathrm{GABA}_{\mathrm{A}}$ receptor (an AED target) during normal neurodevelopment, a process tightly coupled to developmental expression of the chloride cotransporter proteins $\mathrm{NKCC} 1$ and $\mathrm{KCC} 2$. The timing of the 'switch' in $\mathrm{GABA}_{\mathrm{A}}$ receptor function from excitation to inhibition is unclear and in human may not be completed until 3-4 months of age. The aim of this project was to establish the developmental profile of NKCC1, KCC2 and the GABA $\mathrm{A}_{\mathrm{A}}$ receptor $\alpha_{1}$ and $\alpha_{3}$ subunits in piglet brain.

Methods: Preterm and term piglets of several different gestational ages around birth were obtained by caesarean section or spontaneous delivery. Brain tissue was collected from several brain regions and expression analysed by western blot.

Results: In parietal cortex the switch between NKCC1 and KCC2 and, GABA $\mathrm{A}$ receptor $\alpha_{1}$ and $\alpha_{3}$ expression was evident by P3. The switch in $\mathrm{GABA}_{\mathrm{A}}$ receptor $\alpha_{1}$ and $\alpha_{3}$ expression had not yet occurred in the frontal, temporal or occipital cortex. $\mathrm{NKCC} 1, \mathrm{KCC} 2$ analysis is ongoing.

Conclusions: Efficacy of AEDs in neonatal brain may depend on regional and temporal maturation of inhibition. Furthermore changes in $\mathrm{GABA}_{\mathrm{A}}$ receptor expression as we have demonstrated following $\mathrm{HI}$ and seizures will influence receptor pharmacology. There is a critical need to develop effective treatment strategies specific to the neonatal brain. 